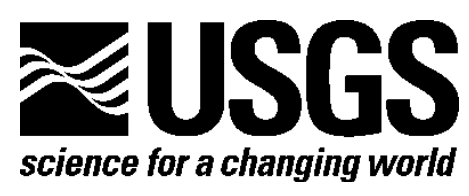

\title{
Socioeconomic Issues for the Bear River Watershed Conservation Area Land Protection Plan
}

By Catherine Cullinane Thomas, Christopher Huber, William Gascoigne, and Lynne Koontz

Open-File Report 2012-1039 


\section{U.S. Department of the Interior \\ KEN SALAZAR, Secretary}

\section{U.S. Geological Survey \\ Marcia K. McNutt, Director}

U.S. Geological Survey, Reston, Virginia: 2012

For more information on the USGS-the Federal source for science about the Earth,

its natural and living resources, natural hazards, and the environment-visit

http://www.usgs.gov or call 1-888-ASK-USGS

For an overview of USGS information products, including maps, imagery, and publications, visit $h$ ttp://www.usgs.gov/pubprod

To order this and other USGS information products, visit http://store.usgs.gov

Suggested citation:

Thomas, C.C., Huber, Christopher, Gascoigne, William, and Koontz, Lynne, 2012, Socioeconomic issues for the Bear River Watershed Conservation Land Area Protection Plan: U.S. Geological Survey Open-File Report 2012-1039, 15 p.

Any use of trade, product, or firm names is for descriptive purposes only and does not imply endorsement by the U.S. Government.

Although this report is in the public domain, permission must be secured from the individual copyright owners to reproduce any copyrighted material contained within this report. 


\section{Contents}

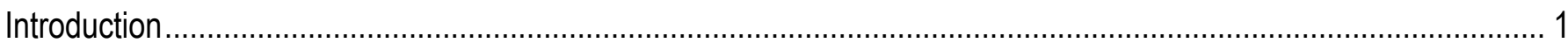

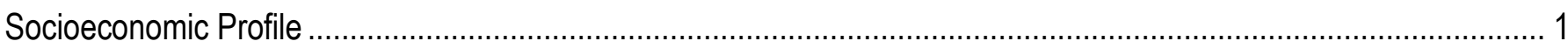

Population

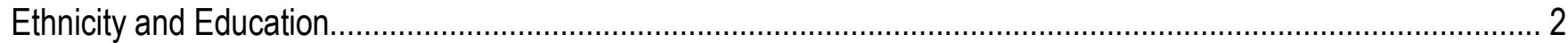

Regional Economy, Employment, and Income …………..................................................................... 3

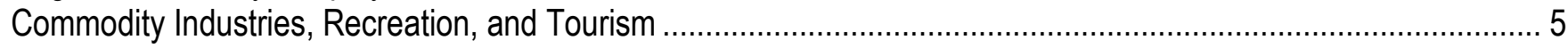

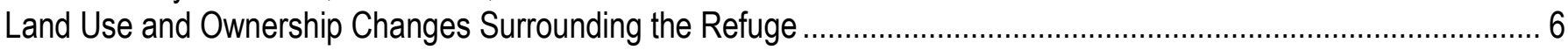

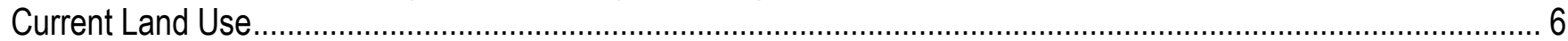

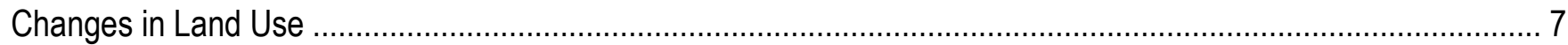

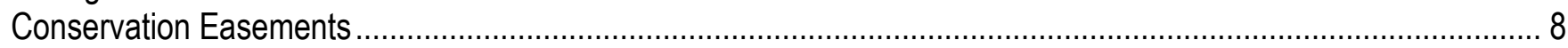

Social and Economic Impacts of Conservation Easements ............................................................................. 9

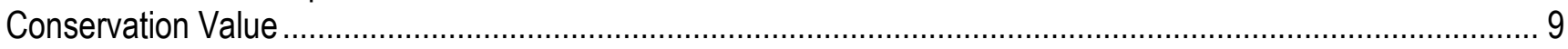

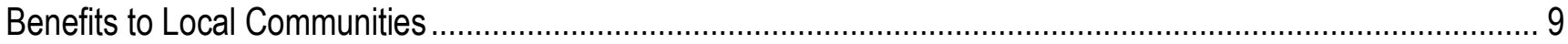

Landowner Compensation.................................................................................................................

Effects on Local Government Net Revenue ...........................................................................................11

Effects on Local Government Revenues .........................................................................................11

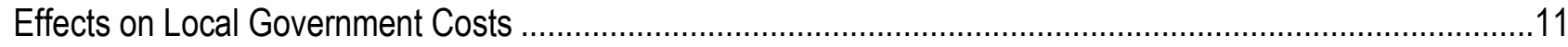

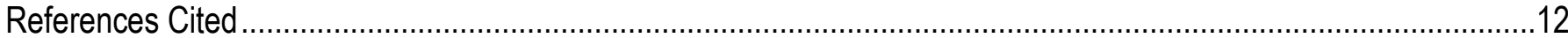

\section{Tables}

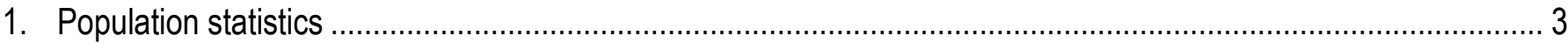

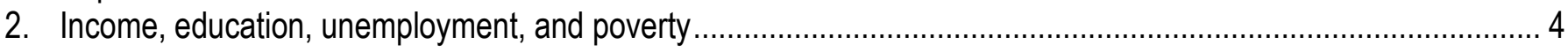

3. Percentage employment by sector ................................................................................................ 5

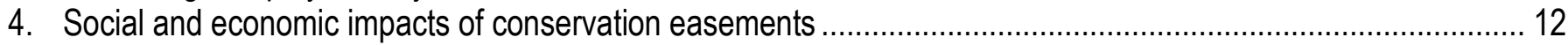




\title{
Socioeconomic Issues for the Bear River Watershed Conservation Area Land Protection Plan
}

\author{
By Catherine Cullinane Thomas, Christopher Huber, William Gascoigne, and Lynne Koontz
}

\section{Introduction}

The Bear River Watershed Conservation Area (BRWCA) is located in the Bear River Watershed, a vast basin covering fourteen counties across three states. Located in Wyoming, Utah, and Idaho, the watershed spans roughly 7,500 squares miles $\left(\mathrm{mi}^{2}\right): 1,500 \mathrm{mi}^{2}$ in Wyoming; 2,700 $\mathrm{mi}^{2}$ in Idaho; and 3,300 $\mathrm{mi}^{2}$ in Utah (Utah Division of Water Resources, 2004). Three National Wildlife Refuges are currently contained within the boundary of the BRWCA: the Bear River Migratory Bird Refuge in Utah, the Bear Lake National Wildlife Refuge in Idaho, and the Cokeville Meadows National Wildlife Refuge in Wyoming.

In 2010, the U.S. Fish and Wildlife Service (the Service) conducted a Preliminary Project Proposal (PPP), and identified the BRWCA to have high value wildlife habitat. This finding initiated the Land Protection Planning (LPP) process, which is used by the Service to study land conservation opportunities including adding lands to the National Wildlife Refuge System (the Refuge System). The Service proposes to include part of the BRWCA in the Refuge System by acquiring up to 920,000 acres of conservation easements from willing landowners to maintain landscape integrity and habitat connectivity in the region. The analysis described in this report provides a profile of the social and economic conditions in the BRWCA and addresses social and economic questions and concerns raised during public involvement in the LPP process.

\section{Socioeconomic Profile}

\section{Population}

The Bear River Watershed Conservation Area (BRWCA) spans fourteen counties: two in Wyoming, six in Utah, and six in Idaho. Table 1 lists population statistics for these fourteen counties and three additional counties (Bonneville County, Idaho; Teton County, Idaho; and Teton County, Wyo.), which, although outside of the watershed basin, have significant economic importance to the region. The fourteen-county region (which excludes the three out-of-basin counties) has a population of roughly 2.9 million people (U.S. Census Bureau, 2010). Population growth is expected throughout much of the region with most of the growth centered on the Cache Valley. Located in the western portion of the Bear River Basin in Utah, the Cache Valley is currently the most populated area in the basin. The valley's population is estimated to double from 2000 levels to 297,597 by 2050 (Utah Division of Water Resources, 2004). Population growth in the Cache Valley is partly due to the valley's proximity to the metropolitan Wasatch Front. The eastern portion of the basin has historically been sparsely populated and is expected to continue on this trend (Toth and others, 2010). The northern portion of the basin (which includes the Star Valley) and the three out-of-basin counties of interest (which include the Teton Valley) have high development value and are likely to face management issues in the future.

The State of Utah has experienced a population increase of 24 percent from 2000 to 2010 (U.S. Census Bureau, 2010). The six Utah counties that are part of the Bear River Watershed have experienced 
similar population-growth trends. With more than 112,000 residents, Cache County has grown the fastest with a population increase of 64 percent since 2000, and has the second largest population among the six Utah counties. Weber County, which has grown by 18 percent since 2000, has the largest population among these six counties with more than 231,000 residents, and has the highest population density with 402 persons $/ \mathrm{mi}^{2}$. The population in Box Elder County, where the Bear River Migratory Bird Refuge is located, has grown by 17 percent in the last decade.

Idaho has experienced similar growth in population with an increase of 21 percent since 2000 (U.S. Census Bureau, 2010). However, unlike Utah, not all Idaho counties that are part of the BRWCA have experienced an increase in population. Two counties, Caribou County and Bear Lake County, have decreased in population by 5 percent and 7 percent, respectively. Bear Lake County, where the Bear Lake National Wildlife Refuge is located, has a population of nearly 6,000 residents. With nearly 83,000 residents, Bannock County has the largest population of the Idaho counties located within the watershed, and has grown by 10 percent since 2000 (U.S. Census Bureau, 2010).

The population in Wyoming has increased by 14 percent since 2000 (U.S. Census Bureau, 2010). Lincoln County, home to the Cokeville Meadows National Wildlife Refuge, has grown by 24 percent since 2000, making it the county with the fastest growing population among the Wyoming counties in the conservation area.

Bonneville County, Idaho, Teton County, Idaho, and Teton County, Wyo., are included in the socioeconomic profile due to their development patterns and their potential economic impacts on the entire watershed; however, they are not part of the fourteen-county region in which the BRWCA is located. Among the Idaho counties in table 1, Teton County and Bonneville County have experienced the greatest population growth since 2000, with Teton County growing by 70 percent and Bonneville County growing by 26 percent over the decade. Bonneville County has the largest population of the Idaho counties with more than 100,000 residents, and includes a portion of the Star Valley which has experienced high development rates in recent years. The Star Valley straddles the Idaho-Wyoming border roughly 30 miles north of the BRWCA. Further north of Star Valley is Teton Valley, which spans the Idaho-Wyoming border into Teton County, Idaho and Teton County, Wyo. The population in Teton County, Idaho and Teton County, Wyoming has increased by 70 percent and 17 percent, respectively, since 2000 (U.S. Census Bureau, 2010). These two regions, Star Valley and Teton Valley, have potentially high development values and may impact the Bear River Watershed in the future.

\section{Ethnicity and Education}

Relative to other counties in the fourteen-county region, Power County, Idaho has the largest percentage of individuals who identified as Hispanic or Latino on the 2010 Census (30 percent of the population) (U.S. Census Bureau, 2010). Power County, Idaho also had the lowest percentage of persons who identified as white (75 percent of the population). Cokeville County, Wyo., and Morgan County, Utah, had the lowest percentage of persons who identified as Hispanic or Latino (2 percent of the population). Cokeville, Wyo., had the highest percentage of individuals who identified as white (99 percent of the population).

Table 2 shows the percent of the population that has obtained a bachelor's degree or higher within each of the BRWCA states and counties. Of the three states, Utah has the highest percentage of individuals with at least a bachelor's degree (29 percent of the population), followed by Idaho ( 24 percent) and Wyoming (23 percent) (U.S. Census Bureau, 2010). Among the Utah counties, Summit County and Cache County have a higher percentage of the population with a bachelor's degree relative to the state average (48 percent and 35 percent, respectively). Among Idaho counties, Teton County, Bannock County, and Bonneville County have greater percentages of the population with a bachelor's degree or higher relative to the state average (28 percent, 27 percent and 26 percent of residents, respectively). In 
Table 1. Population statistics for counties in Utah, Idaho, and Wyoming that contain the Bear River Watershed Conservation Area (BRWCA).

\begin{tabular}{lrrc}
\hline & Residents (2010) & Persons per square mile & $\begin{array}{c}\text { Percentage population } \\
\text { change since 2000 }\end{array}$ \\
\hline Utah & $2,763,885$ & 33.6 & 24 \\
Cache County & 112,656 & 96.7 & 64 \\
Rich County & 2,264 & 2.2 & 16 \\
Summit County & 36,324 & 19.4 & 22 \\
Weber County & 231,236 & 401.8 & 18 \\
Morgan County & 9,469 & 15.5 & 33 \\
Box Elder County & 49,975 & 8.7 & 17 \\
\hline Idaho & $1,567,582$ & 18.9 & 21 \\
Power County & 7,817 & 5.6 & 4 \\
Bannock County & 82,839 & 74.4 & 10 \\
Oneida County & 4,286 & 3.6 & 4 \\
Franklin County & 12,786 & 19.2 & 13 \\
Caribou County & 6,963 & 3.9 & -5 \\
Bonneville County & 101,234 & 55.8 & 26 \\
Teton County & 10,170 & 22.6 & 70 \\
Bear Lake County & 5,986 & 6.2 & -7 \\
\hline Wyoming & 563,626 & 5.8 & 14 \\
Uinta County & 21,118 & 10.1 & 7 \\
Teton County & 21,294 & 5.3 & 17 \\
Lincoln County & 18,106 & 4.4 & 24 \\
\hline Sour & & &
\end{tabular}

Source: (Utah Governors Office of Planning Budget, 2008)

${ }^{\mathrm{a}}$ Indicates counties outside of the BRWCA

Wyoming, the only county with a rate higher than the state average is Teton County, with 50 percent of residents having a bachelor's degree or higher.

\section{Regional Economy, Employment, and Income}

Table 2 shows median household income and poverty rates for each of the BRWCA States and counties. Among the three States, Utah had the highest median household income in $2009(\$ 55,183$ per year), followed by Wyoming $(\$ 54,400)$, and Idaho $(\$ 44,644$ per year) (U.S. Census Bureau, 2009). Idaho had the highest statewide poverty rate at 14.4 percent, and Wyoming had the lowest (10.2 percent). Within the fourteen-county region, Morgan County, Utah had the highest median household income $(\$ 75,164$ per year) and the lowest poverty rate (4.9 percent). Power County, Idaho had the lowest median household income $(\$ 38,509$ per year) and one of the highest poverty rates (16.6 percent). The highest poverty rate in the fourteen-county region was in Cache County at 16.7 percent. Although all but two of the counties in Idaho had poverty rates less than the statewide average, none had a poverty rate less than 10 percent. In 2009, each of the counties in Wyoming had a poverty rate lower than the statewide average and a median household income level higher than statewide average. (U.S. Census Bureau, 2009) 
Table 2. Income, education, unemployment, and poverty rates for counties in Utah, Idaho, and Wyoming that contain the Bear River Watershed Conservation Area (BRWCA).

\begin{tabular}{|c|c|c|c|c|c|}
\hline & \multirow{2}{*}{$\begin{array}{l}\text { Median household } \\
\text { income (2009) }\end{array}$} & \multirow{2}{*}{$\begin{array}{l}\text { Bachelor's degree } \\
\text { or higher }\end{array}$} & \multicolumn{2}{|c|}{ Percentage unemployed } & \multirow{2}{*}{$\begin{array}{l}\text { Percentage of } \\
\text { individuals belou } \\
\text { poverty (2009) }\end{array}$} \\
\hline & & & 2008 & 2011 & \\
\hline Utah & $\$ 55,183$ & 29 & 3.8 & 7.5 & 11.7 \\
\hline Cache County & $\$ 47,064$ & 35 & 2.9 & 6.0 & 16.7 \\
\hline Rich County & $\$ 53,783$ & 26 & 2.8 & 4.9 & 10.1 \\
\hline Summit County & $\$ 73,769$ & 48 & 3.5 & 6.6 & 7.3 \\
\hline Weber County & $\$ 53,094$ & 22 & 4.4 & 8.7 & 12.5 \\
\hline Morgan County & $\$ 75,164$ & 25 & 3.5 & 6.3 & 4.9 \\
\hline Box Elder County & $\$ 52,867$ & 22 & 4.2 & 9.3 & 9.6 \\
\hline Idaho & $\$ 44,644$ & 24 & 4.8 & 9.4 & 14.4 \\
\hline Power County & $\$ 38,509$ & 20 & 5.0 & 8.4 & 16.6 \\
\hline Bannock County & $\$ 44,451$ & 27 & 4.4 & 8.4 & 14.5 \\
\hline Oneida County & $\$ 43,057$ & 16 & 3.3 & 5.3 & 12.8 \\
\hline Franklin County & $\$ 45,404$ & 16 & 3.1 & 6.0 & 10.6 \\
\hline Caribou County & $\$ 51,060$ & 18 & 3.4 & 7.4 & 10.9 \\
\hline Bonneville County ${ }^{\mathrm{a}}$ & $\$ 49,446$ & 26 & 3.3 & 7.1 & 11.9 \\
\hline Teton County ${ }^{\mathrm{a}}$ & $\$ 57,999$ & 28 & 2.7 & 5.2 & 10.3 \\
\hline Bear Lake County & $\$ 42,199$ & 16 & 3.1 & 5.0 & 13.0 \\
\hline Wyoming & $\$ 54,400$ & 23 & 3.2 & 5.8 & 10.2 \\
\hline Uinta County & $\$ 64,284$ & 17 & 2.9 & 5.1 & 9.0 \\
\hline Teton County $^{\mathrm{a}}$ & $\$ 68,777$ & 50 & 3.0 & 4.6 & 5.8 \\
\hline Lincoln County & $\$ 59,160$ & 17 & 3.6 & 6.6 & 8.0 \\
\hline
\end{tabular}

Sources: U.S. Census Bureau, 2009 (mean household income and percentage of individuals below poverty in 2009)

(Bureau of Labor Statistics, 2011a) (July 2011 unemployment)

(Bureau of Labor Statistics, 2011b) (2011 county unemployment estimates)

(Bureau of Labor Statistics, 2008) (2008 county unemployment estimates)

${ }^{a}$ Indicates counties outside of the BRWCA

Table 3 shows the percent of employment by sector within the fourteen-county region. The combined fourteen-county region had a total non-farm employment of more than 265,000 individuals in 2010 (U.S. Census Bureau, 2011). The highest percentage of total employment was found in educational services, health care, and social assistance (20 percent of non-farm employment). This is in part due to the high population and abundance of educational and health care centers in Cache County, Utah (home to Utah State University) and Weber County, Utah. The second and third highest percentage of total employment in 2010 was in manufacturing (14 percent) and retail trade (12 percent). Agriculture, forestry, fishing, hunting, and mining made up an estimated 4 percent of the total employment by sector. 
Table 3. Percentage employment by sector for counties in Utah, Idaho, and Wyoming that contain the Bear River Watershed Conservation Area (BRWCA).

\begin{tabular}{lc}
\hline Employment sectors & $\begin{array}{c}\text { Percentage of fourteen } \\
\text {-county region employed }\end{array}$ \\
\hline Total non-farm employment in $2010^{\text {a }}$ & 265,495 \\
Agriculture, forestry, fishing, hunting, and mining & 4 \\
Construction & 8 \\
Manufacturing & 14 \\
Wholesale trade & 3 \\
Retail trade & 12 \\
Transportation and warehousing, and utilities & 4 \\
Information & 2 \\
Finance and insurance, and real estate, rental, and leasing & 5 \\
Professional, scientific, management, administrative, and waste-management services & 8 \\
Educational services, health care, and social assistance & 20 \\
Arts, entertainment, and recreation, and accommodation and food services & 9 \\
Other services, except public administration & 3 \\
Public administration & 7 \\
\hline
\end{tabular}

Source: U.S. Census Bureau, 2011

${ }^{a}$ Not every sector category for every county was fully disclosed due to confidentiality requirements; the table reflects the best and most accurate information available.

\section{Commodity Industries, Recreation, and Tourism}

Agriculture, forestry, fishing, hunting, and mining accounted for roughly 4 percent of total jobs in the fourteen-county region in 2011 (U.S. Census Bureau, 2011). The total number of agriculture jobs decreased from nearly 14,000 jobs in 1970 to 10,600 in 2009 (U.S. Department of Commerce, 2010a [data complied using EPS-HDT]). Oneida County, Idaho had the largest percentage of employment in agriculture (23 percent), and Weber County, Utah had the smallest (0.87 percent) (U.S. Department of Commerce, 2010a; U.S. Department of Commerce, 2010b [data complied using EPS-HDT]). Weber County, Utah also had the smallest percentage of land area in agriculture (29 percent), while Morgan County, Utah had the largest (more than 77 percent of total land in agriculture) (U.S. Departmnet of Agriculture, 2009 [data complied using EPS-HDT]) .

Regional employment in timber represents a small fraction of total employment and has decreased in the fourteen-county region since 1999 (U.S. Department of Commerce, 2010b [data complied using EPS-HDT]). As a percentage of the total regional employment, timber has decreased from 0.76 percent to 0.38 percent from 1998 to 2009 . During this period, employment in timber-related fields shrank from 1,500 to 877 jobs (a 41-percent decrease); sawmill and paper mill employment decreased by 71 percent, and wood product manufacturing declined by 35 percent.

Mining also represents a relatively small percentage of total employment for many of the counties in the region, but has increased slightly since 1998 (U.S. Department of Commerce, 2010b [data complied using EPS-HDT]). Mining accounted for less than 1 percent of total employment in 2009 for all but three counties in the fourteen-county region. Caribou County, Idaho had more than 23 percent of total employment in mining; Oneida County, Idaho had more than 12 percent, and Franklin County, Idaho had 2.5 percent. The combined region had roughly 0.6 percent of total employment in mining in 2009 , up from 0.38 percent in 1998. From 1998 to 2009, the total number of mining jobs in the region increased by 84 
percent from 750 jobs to 1,381 jobs. Within the mining sector, nonmetallic mineral mining jobs increased by 124 percent, oil and gas extraction jobs decreased by 64 percent, and metal ore mining jobs decreased to zero jobs by 2009 (U.S. Department of Commerce, 2010b [data complied using EPS-HDT]). One of the most economically significant non-metallic mining activities during the past 50 years has been phosphate extraction, with roughly 40 percent of the U.S. reserves located in southeastern Idaho (Van Every, 2004).

According to the 2006 National Survey of Fishing, Hunting, and Wildlife-Associated Recreation, approximately 2.9 million residents participated in wildlife-associated recreation activities in Utah, Idaho, and Wyoming in 2006 (U.S. Fish and Wildlife Service, 2008). It was estimated that residents and visitors combined spent $\$ 3.3$ billion on wildlife-associated recreation activities in 2006 in the three states combined. Among participants, wildlife watching was the most frequently reported activity followed by fishing and hunting. In Wyoming, 84 percent of individuals surveyed watched wildlife, 27 percent fished, and 13 percent hunted; in Utah, 77 percent watched wildlife, 33 percent fished, and 15 percent hunted; and in Idaho, 75 percent watched wildlife, 35 percent fished, and 19 percent hunted (U.S. Fish and Wildlife Service, 2008). Following the national trend, wildlife viewing has become increasingly popular while hunting and fishing have decreased or remained stable in popularity. From 1996 to 2006, it was found that the number of Idaho residents who went fishing declined by 21 percent and hunting declined by 33 percent. Wyoming residents who went fishing declined by 19 percent, while hunting and wildlife viewing numbers remained relatively constant. During the same time period, Utah residents who watched wildlife increased by 30 percent, while hunting and fishing remained relatively constant.

\section{Land Use and Ownership Changes Surrounding the Refuge}

\section{Current Land Use}

The Bear River originates in the Uinta-Wasatch-Cache National Forest in Utah's Uinta Mountains, meanders through the mountains and foothills of Utah and Wyoming into the foothills and valleys of Idaho and Utah, and terminates its course in the Great Salt Lake. The Upper Bear River area is located in part of Summit and Uinta counties, Utah, and Lincoln County, Wyo. The headwaters of the Bear River, near the border of Summit and Uinta counties, is forested; the remaining land cover in the high elevation Upper Bear River area is primarily grasslands and shrublands, with about three-quarters of the land used for grazing (Utah Water Research Laboratory, 2011). As of 2006, about 63 percent of the land in the Upper Bear counties was federally owned, primarily by the Bureau of Land Management and the U.S. Forest Service; about 24 percent of the land was privately owned, 4 percent was State owned, and 7 percent was tribally owned (Conservation Biology Institute, 2006 [data complied using EPS-HDT]). Very few people live in the Upper Bear River area; the largest municipalities in the region are Evanston and Cokeville, Wyo., and Randolph and Woodruff, Utah (Utah Water Research Laboratory, 2011).

The Middle Bear River area is located in part of Bear Lake, Caribou, Franklin, Bannock, Oneida, and Power Counties in Idaho. Grasslands and shrublands account for about 77 percent of the land cover in the Middle Bear Counties, and croplands account for about 11 percent of the land cover. As of 2006, urban development accounts for only about 0.2 percent of the land cover in these counties; the largest municipalities in the region are Grace, Preston, Montpelier, Soda Springs, and Malad City, Idaho, and Richmond, Smithfield, North Logan, and Garden City, Utah (NASA, 2006 [data complied using EPSHDT]); Utah Division of Water Resources, 2004). As of 2006, landownership in the Middle Bear River counties was 48 percent private, 38 percent Federal, 5 percent state, and 6 percent tribal (Conservation Biology Institute, 2006 [data complied using EPS-HDT]).

The Lower Bear River area includes part of Box Elder, Cache, Rich, Weber, and Morgan Counties in Utah. The rich soil and abundant water in this portion of the Bear River Basin support a mix of urban and agricultural uses. About 9 percent of the land cover in the Lower Bear counties is water. Mixed 
croplands account for 21 percent of the land cover in the Lower Bear counties, with croplands concentrated in Cache, Weber, and Morgan Counties (NASA, 2006 [data complied using EPS-HDT]). As of 2006, about 1.6 percent of the land in these counties is urban development, with much of the development concentrated in the Cache Valley (NASA, 2006 [data complied using EPS-HDT]). Major municipalities within the Lower Bear River area include Ogden, Brigham City, Logan, and Tremonton, Utah. As of 2006, landownership in the Lower Bear counties was 52 percent private, 31 percent Federal, and 6 percent state owned (Conservation Biology Institute, 2006 [data complied using EPS-HDT]).

\section{Changes in Land Use}

The Bear River watershed is located in both the Pacific and Central migratory flyways, and provides one of the most significant resting, staging, feeding, breeding, and nesting areas for large populations of migratory birds and waterfowl traveling these flyways (U.S. Fish and Wildlife Service, 2010). The watershed also provides habitat for species such as the Greater sage grouse, Columbian sharptailed grouse, Bonneville cutthroat trout, pronghorn antelope, grizzly bear, Canada lynx, wolverine, and gray wolf (U.S. Fish and Wildlife Service, 2010). These species benefit from the three existing refuges in the watershed but also utilize and depend on adjacent public and private lands and waters. In 2009, The Nature Conservancy (TNC) conducted a Conservation Action Planning (CAP) study in the Bear River Watershed and found residential development and water-allocation policies to be the greatest threats to wildlife conservation in the watershed (The Nature Conservancy, 2010).

Much of the land cover in the BRWCA is comprised of a mix of public lands and large tracts of privately owned ranchlands and croplands. Private ranchlands and croplands provide dual benefits by supplying wildlife habitat on working landscapes. These valuable landscapes are threatened by residential development. In 2000, the American Farmland Trust identified 4.0 million acres of prime ranchlands ${ }^{1}$ in Idaho, 3.4 million acres in Utah, and 2.6 million acres in Wyoming as being vulnerable to low-density development by the year 2020, with ranchlands located in high mountain valleys and mixed grassland areas surrounding the Rocky Mountains at highest risk of conversion. Within the Rocky Mountain Region (which includes 263 counties in Idaho, Montana, Wyoming, Utah, Colorado, Arizona, and New Mexico), Uinta County, Wyo., and Summit County, Utah ranked in the top 25 counties for acres of strategic ranchland $^{2}$ at risk (American Farmland Trust, 2000).

Development risk for ranchlands and farmlands is largely driven by population growth and housing demand. Human populations have been expanding rapidly in the three Bear River states, and are projected to continue growing. The Utah Governor's Office of Planning and Budget projects that the population in Utah will increase by more than 250 percent between 2008 and 2060 (from 2.7 million to 6.84 million people), with Cache and Box Elder Counties housing an increasing share of the state's population. To accommodate this growth, 32,000 new households are expected to be built statewide every year, resulting in a 75 percent increase in developed land and a 7.3 percent loss of agricultural land by 2030 (Utah Governors Office of Planning and Budget, 2008). In Wyoming, Lincoln County has seen a 24.3 percent population growth over the last decade (U.S. Census Bureau, 2010), with about 200 new homes built each year (Royster and Gearino, 2006), and Uinta County has experienced 7.0 percent population growth over the decade. Ranches in the Star Valley (located in Lincoln County, just south of Teton County) are rapidly being lost to development. The picturesque Star Valley is in close proximity to Jackson Hole and has become a popular location for second-home owners and people commuting to Jackson. High land prices have spurred many longtime ranchers to sell their land to developers (Royster and Gearino, 2006). The Valley once supported about 200 full-time dairy operations; as of 2006, there

\footnotetext{
${ }^{1}$ Prime ranchlands are defined as ranchland with high quality agricultural land and desirable wildlife characteristics.

${ }^{2}$ Strategic ranchlands are defined as both prime and threatened. Threatened ranchlands are located in rural areas projected to grow to suburban density within 20 years or are along major road corridors in counties with growth rates great than 10 percent per decade.
} 
were only about six dairy farms left (Royster and Gearino, 2006). Idaho has also seen a large boom in population over the past decade. The percent of population growth in Idaho ranks fourth nationally, with 21 percent growth between 2000 and 2010 (U.S. Census Bureau, 2010). Much of the growth in Idaho has been in urban areas, with 80 percent of the State's growth occurring in metropolitan counties (State of Idaho Department of Labor, 2011). Idaho counties within the BRWCA have seen less growth, and Bear Lake and Caribou counties have seen a decline in population over the decade. Of the BRWCA counties in Idaho, Franklin and Bannock counties have experienced the greatest growth (12.9 percent and 9.6 percent growth over the decade, respectively).

Ecosystems in the three existing refuges in the Bear River Watershed are highly dependent on water availability. Since the Bear River Watershed is considered one of the last areas of Utah with a developable water supply, there is a concern that development pressure and demand for water will negatively impact sensitive refuge habitat and ecosystems (Toth and others, 2010). With much of the undeveloped water claimed by municipalities along the Wasatch Front, it has been estimated that one fifth of the current Bear River flows could be diverted within the next 50 years (Utah State University Extension, 2006). Agricultural operations, roads, dams, and grazing practices along sensitive riparian environments have contributed to the degradation of the main stem Bear River (Utah State University Extension, 2006; Utah Water Research Laboratory, 2011). Although flood irrigation has provided water for many waterfowl that use the valley, irrigation threatens to lower the water table of the watershed and in turn threatens ranching and conservation efforts.

\section{Conservation Easements}

One of the Service's high-priority objectives is to guide residential and commercial development away from high-priority conservation areas by securing appropriate conservation easements. The purpose of the BRWCA is to conserve critical resources in the watershed that have direct positive impacts on the management of the three existing refuges (U.S. Fish and Wildlife Service, 2010). Conservation of these key habitats will be accomplished through the purchase of conservation easements from willing land owners. Conservation easements leave land in private ownership, protecting private property rights, while providing the Service with a cost-effective conservation strategy that enables the conservation of large blocks of habitat. Within the BRWCA, the Service proposes to protect up to 920,000 acres of significant wildlife habitat to maintain landscape integrity and habitat connectivity (U.S. Fish and Wildlife Service, 2010).

A conservation easement is a voluntary legal agreement entered into between a landowner and a conservation entity. Conservation easements are binding in perpetuity; the landowner reserves the right to sell or bequeath the property, but the easement and its associated restrictions remain with the property in perpetuity. Under a conservation easement, a landowner maintains ownership of their property, but transfers some of their ownership rights to the conservation entity. Landowners have a set of rights associated with their land. For example, landowners have the right to run cattle, grow crops, harvest trees, build structures, and subdivide and sell part of their land. The most common right transferred under a conservation easement is the right to develop or subdivide the land.

Conservation easements in the BRWCA may require the transfer of additional rights. A conservation easement on a parcel of land may have restrictions on the development of vertical structures (including wind turbines and buildings). The significant concern with vertical structures in the Bear River Watershed is the potential negative impact on sage grouse populations; a conservation easement that precludes vertical structures may protect critical sage grouse habitat cover. Roughly 60 percent of the Bear River Watershed is shrub-steppe, and protection of this land cover may provide an opportunity for crucial habitat protection for sage grouse (Dobkin and Sauder, 2004; Rich and others, 2005; Rowland and others, 2005). Water sources on private lands also provide critical habitat in the BRWCA. Protecting these sources of water will be a key objective within the Conservation Area, and easement agreements may 
include restrictions on the sale or diversion of water from the land. Water laws are sensitive to State requirements; therefore, water issues will need to be addressed individually for each easement (Utah State University Extension, 2006). In all cases, the terms of a conservation easement must be mutually agreed upon by the landowner and the easement holder.

Subsurface rights are often severed from the surface rights of a parcel of land. Conservation easements only apply to surface rights; therefore the mineral interest may be extracted at any time by the person who holds the qualified mineral right (Byers and Ponte, 2005). For this reason, the Service is unlikely to enter into a conservation easement agreement for a parcel of land that has a viable subsurface mineral interest. Exceptions may be made if the parcel has high habitat value and the probability of mineral extraction is low.

\section{Social and Economic Impacts of Conservation Easements}

Conservation easements are a public good that generate benefits for local residents, communities, and governments. Easements also reshape future development patterns, affect property values, and inject new money into local communities. There are many dynamic variables at play when considering the social and economic effects of conservation easements. This analysis addresses the following effects of conservation easements in the BRWCA:

- Conservation values in the region,

- Benefits to local communities,

- Landowner compensation, and

- Effects to local government net revenue.

Table 4, located at the end of this section, provides a summary of the social and economic impacts of conservation easements in the BRWCA.

\section{Conservation Value}

Conservation easements can protect values associated with biodiversity and wildlife abundance, maintain aesthetic beauty, and protect social and culturally significant features of landscapes and livelihoods (Millennium Ecosystem Service Assessment, 2005; Ehrlich and Ehrlich, 1992; Daily, 1997). Ecosystem services, such as water purification, oxygen production, pollination, and waste breakdown, are also maintained for local residents through conservation easements (Millennium Ecosystem Service Assessment, 2005). The primary public benefit of Service conservation easements is enhanced and preserved wildlife habitat. As development stressors increase over time, many key off-refuge habitat areas may become less available due to conversion to non-wildlife habitat uses. Habitat preservation has been shown to stabilize and increase wildlife populations (Reynolds and others, 2001). Conservation easements on private lands strengthen the resiliency of species habitat and provide opportunities for wildlife movement and adaptation for years to come.

\section{Benefits to Local Communities}

Although local residents may not be able to explicitly use or access land protected by conservation easements, protected lands act as a buffer which benefits residents through increased biodiversity, recreational quality, and hunting opportunities on publicly accessible wildlife refuges and on some private lands (Rissman and others, 2007). It is well documented that open space carries positive values to local residents and communities, as well as to passers-by (McConnell and Walls, 2005). This is evidenced by the success of open space preservation ballot initiatives at the local, county, and state levels. Banzhaf and others (2006) point out that between 1997 and 2004, over 75 percent of the more than 1,100 referenda on open space conservation that appeared on ballots across the United States passed, most by a wide margin. 
It is also well documented that open space and protected natural areas can increase surrounding property values (see McConnell and Walls, 2005, for a comprehensive review). The reciprocating value of open space on property values will vary depending on landscape characteristics and location attributes (for example, distance to the conserved area) (Kroger, 2008). The permanence of the open space is also an influencing factor. Typically, open space that is permanently protected (such as refuge lands and lands protected with perpetual conservation easements) will generate a higher enhancement value of local properties than land that has the potential for future development (Geoghegan and others, 2003). Location and demographic factors in the region can also influence the relative level of property enhancement value. For instance, open space may generate larger amenity premiums for property in more urbanized areas and where median incomes are higher (Netusil and others, 2000); this is not to say there isn't the chance for property values to increase substantially in rural areas as well (Vrooman, 1978; Phillips, 2000; Crompton, 2001; Thorsnes, 2002).

Conservation easement purchases may also inject new money into the local economy. The sale of conservation easements provides landowners with additional revenue. Landowners may spend some percentage of these funds in the local economy, including purchasing new real estate, consumer goods, or services in the local area. This spending activity can directly impact local industries (such as construction and various service sectors), with additional indirect impacts to follow suit.

Conservation easements may also help maintain the character of a region by protecting a traditional and historic way of life and the associated working landscape. Land with historic commercial use, such as ranching, forestry, and farming, is often compatible with or beneficial to wildlife refuge objectives (Jordan and others, 2007; Rissman and others, 2007). Conservation easements provide financial benefits for landowners that may enable them to preserve the natural and historic value of their farm, ranch, and open space lands, and to pass this legacy on to their children and grandchildren.

\section{Landowner Compensation}

The Service proposes to buy conservation easements from willing sellers at fair market value. The fair market value of a conservation easement is determined through an appraisal process. An appraiser estimates how much the land would sell for unencumbered by the conservation easement (the "before" value) and how much the land would sell for with the conservation easement in place (the "after" value). The value of the conservation easement is equal to the before value minus the after value, or the difference in the fair market value of the property with and without the easement. Landowners may also choose to donate conservation easements to the Service. The donation of a conservation easement may qualify as a tax-deductible charitable donation, which may result in Federal income tax benefits. The sale of a conservation easement for less than its fair market value (called a "bargain sale") may also qualify for tax deductions. Landowners may be able to claim a charitable income-tax donation equal to the difference between the fair market value and the bargain sale price of their easement. Income from the sale of a conservation easement may be taxable. Please note that the Service does not give tax advice. Landowners considering entering into a conservation agreement with the Service should consult a tax advisor or attorney for advice on how a conservation easement would affect their taxes and estate.

Conservation easements reduce the value of the encumbered property. A conservation easement will reduce the fair market value of an estate, because the easement permanently removes some of the estate's development potential. The reduction in value depends on the potential development value of the land and the level of restriction agreed upon in the easement. In general, an easement on land located in an area with high development pressure will have a greater effect on the value of the land than an easement on land located in an area with low development pressure, and an easement that is more restrictive will have a greater effect on the value of the land than an easement that is less restrictive. The Service will purchase easements at their appraised fair market value; therefore, easements on lands with high development pressure will receive higher payments. 


\section{Effects on Local Government Net Revenue}

The effect of conservation easements on local government net revenue is complex and speculative; many variables are at play, and realizing the effects often requires time. Local governments collect revenue through intergovernmental transfers, property taxes, sales taxes, personal income taxes, and other charges, such as permitting. These revenues are then spent to provide community services such as fire and police services, schools, infrastructure, and public spaces. Conservation easements affect the location of future development, and therefore affect both future revenues and costs for local governments. The following sections describe the possible effects to local government revenues and costs. Overall, the effects of the BRWCA conservation easement program on net revenues (revenues minus costs) to local governments are expected to be marginal.

\section{Effects on Local Government Revenues}

Property taxes constitute the largest source of local governments' own revenue (Urban Institute and Brookings Institution, 2008), and are not expected to be substantially affected by conservation easements in the BRWCA. Property taxes are assessed based on the value of property. For most types of properties, county assessors use fair market value to determine property tax liabilities; however, agricultural land is often assessed differently. In many states, the assessed value of agricultural land is determined based on the productive value of the land rather than on the fair market value of the property. The fair market value of land is the amount that a property is estimated to sell for. This value includes both the productive value of the land and any speculative value associated with the possibility of developing the land. Conservation easements reduce the fair market value of property by removing the speculative value associated with possible development; however, conservation easements generally do not affect the productive value of agricultural land. The BRWCA encompasses three states: Utah, Idaho, and Wyoming. In all three states, property taxes for agricultural land are assessed based on the productive value of the land ${ }^{3}$. The majority of properties that enter into conservation-easement agreements with the Service are classified as agricultural land; thus, there will be little to no impact to the current property tax base for the fourteen-county area.

Local government revenue associated with personal income is also expected to remain relatively constant within the fourteen-county area. Conservation easements in the BRWCA would affect the location and distribution of development, but are not expected to change the rate or density of human population growth. Redistribution of population growth could affect the distribution of personal-incomerelated revenues across the counties, but is expected to have little effect on total revenues within the fourteen-county area.

\section{Effects on Local Government Costs}

Land protection through conservation easements could result in a reduction in future expenditures for local governments and municipalities. New residential developments require local governments to

\footnotetext{
${ }^{3}$ Special rules and statues apply in each state to determine if agricultural land and land in conservation easements is eligible to be assessed as agricultural land. To qualify in each state, land must have previously been in agriculture for a minimum amount of time, meet a minimum acreage requirement, meet minimum production requirements, and be operated in such a way that there is a reasonable expectation of profit (utah.gov, 2011; Idaho State Tax Commission, 2011; Wyoming Department of Revenue, 2011). In all three states, agricultural property that meets these criteria prior to being encumbered with a conservation easement, and continues to meet these criteria after a conservation easement is in place, will be assessed based on productive value (utah.gov, 2011; Idaho State Tax Commission, 2011; Wyoming Department of Revenue, 2011). In Wyoming and Utah, land must remain actively devoted to agricultural use to maintain its assessment status as agricultural land (utah.gov, 2011; Wyoming Department of Revenue, 2011). In Idaho, the Wildlife Habitat Exemption allows land that is managed for wildlife habitat under a qualified conservation agreement to be assessed as agricultural land, whether or not it is operated as a for-profit agricultural operation (Idaho State Tax Commission, 2011).
} 
provide services such as fire protection, police services, and schools, and to construct new infrastructure such as roads, parks, and water and electricity-delivery systems. The costs to provide government services for new residential developments often exceed new revenues derived from the developments. This is especially true for rural residences, which tend to have higher costs to county governments and school districts than urban residences. In 2001, the American Farmland Trust found that, on average, the cost to provide community services to new residential developments was $\$ 1.15$ for every $\$ 1.00$ of revenue

created by those developments (American Farmland Trust, 2001; Coupal and others, 2002). A study conducted in Wyoming found that community service costs averaged $\$ 2.01$ for every $\$ 1.00$ of revenue for rural residential lands; in contrast, the average cost to provide services for lands under agricultural production averaged $\$ 0.54$ for every $\$ 1.00$ of revenue (Taylor and Coupal, 2000).

Table 4. Social and economic impacts of conservation easements

\begin{tabular}{|c|c|}
\hline Issue & Social and economic impacts \\
\hline Conservation value & $\begin{array}{l}\text { Migration corridors and habitat for deer, elk, moose, and migratory birds will } \\
\text { be preserved. }\end{array}$ \\
\hline Benefits to local communities & $\begin{array}{l}\text { - The public will enjoy increased biodiversity, recreational quality, and hunting } \\
\text { opportunities on publicly accessible refuges and some private lands. } \\
\text { - Neighboring property values may increase. } \\
\text { - Positive economic impacts may result from new money injected into the local } \\
\text { economy. } \\
\text { - Traditional and historic ranching and farming landscapes will be preserved. }\end{array}$ \\
\hline Landowner compensation & $\begin{array}{l}\text { - Land owners will be compensated for the fair market value of the easement. } \\
\text { - Lasements will reduce the fair market value of the encumbered property. } \\
\text { develop or subdivide the majority of use rights, but forfeit their right to } \\
\text { development of vertical structures, diversion or sale of water rights, and oil or } \\
\text { mineral extraction. }\end{array}$ \\
\hline $\begin{array}{l}\text { Affects to local government net } \\
\text { revenue }\end{array}$ & $\begin{array}{l}\text { - No changes to property tax revenues are expected for agricultural lands. } \\
\text { - Other government revenues, such as personal income tax, may be } \\
\text { redistributed throughout the region. } \\
\text { - Land protection through conservation easements could result in reduced } \\
\text { future service costs for local governments and municipalities. }\end{array}$ \\
\hline
\end{tabular}

\section{References Cited}

American Farmland Trust, 2000, Strategic ranchland in the Rocky Mountain west-Mapping the threats to prime ranchland in seven western States: Washington D.C., American Farmland Trust, accessed online September 05, 2011, at http://www.farmland.org/resources/rockymtn/default.asp

American Farmland Trust, 2001, Cost of community service studies: Washington D.C., American Farmland Trust.

Banzhaf, S., Oates, W., Sanchirico, J., Simpson, D., and Walsh, R., 2006, Voting for conservation-What is the American electorate revealing? Resources, v. 160, p. 8-12.

Bureau of Labor Statistics, 2008, Labor force data by county-2008 annual averages: Washington D.C., Bureau of Labor Statistics, U.S. Department of Labor, accessed online November 14, 2011, at ftp://ftp.bls.gov/pub/special.requests/la/laucnty08.txt 
Bureau of Labor Statistics, 2011a, Local area unemployment statistics: Washington D.C., Bureau of Labor Statistics, U.S. Department of Labor, accessed online November 14, 2011, at http://www.bls.gov/web/laus/laumstrk.htm

Bureau of Labor Statistics, 2011b, Labor force data by county (not seasonally adjusted)_July 2010_ August 2011: Washington D.C., Bureau of Labor Statistics, U.S. Department of Labor, accessed online November 14, 2011, at http://www.bls.gov/lau/laucntycur 14.txt

Byers, E., and Ponte, K., 2005, The conservation easement handbook: Washington, D.C., Land Trust Alliance and San Fransisco, The Trust for Public Land, 555 p.

Conservation Biology Institute, 2006, Protected Areas Database, compiled using Headwaters Economics Economic profile system-human dimensions toolkit

Coupal, R., Tayor, D.T., and McLeod, D., 2002, The cost of community services for rural residential development in Wyoming: Laramie, Wyo., Wyoming Open Spaces, 4 p.

Crompton, J., 2001, The impact of parks on property values - A review of the empirical literature: Journal of Leisure Research, v. 33, no. 1, p. 1-31.

Daily, G., 1997, Nature's services: Washington D.C., Island Press.

Dobkin, D.S., and Sauder, J.D., 2004, Shrubsteppe landscapes in jeopardy_Distributions, abundances, and the uncertain future of birds and small mammals in the intermountain west: Bend, Oreg., High Desert Ecological Research Institute, 199 p.

Ehrlich, P., and Ehrlich, A., 1992, The value of biodiversity: Ambio, v. 21, no. 3, p. 219-226.

Geoghegan, J., Lynch, L., and Bucholtz, S., 2003, Capitalization of open spaces into housing values and the residential property tax revenue impacts of agricultural easement programs: Agricultural and Resource Economics Review, v. 32, no. 1, p. 33-45.

Headwaters Economics, 2011, Economic profile system-human dimensions toolkit (EPS-HDT), available for download online at http://headwaterseconomics.org/tools/eps-hdt, downloaded September 05, 2011

Idaho State Tax Commission, 2011, Homeowners and property tax: accessed online September 05, 2011, at http://tax.Idaho.gov/i-1051.cfm

Jordan, N., Boody, G., Broussard, W., Glover, J., Keeney, D., McCown, B., and others, 2007, Sustainable development of the agricultural bio-economy: Science, v. 316, p. 1570-1571.

Kroger, T., 2008, Open space property value premium analysis: Washington D.C., National Council for Science and the Environment, Wildlife Habitat Policy Research Program; Conservation Economics Program, Defenders of Wildlife.

McConnell, V., and Walls, M., 2005, The value of open space-Evidence from studies of nonmarket benefits: Washington D.C., Resources for the Future, 79 p.

Millennium Ecosystem Service Assessment, 2005, Ecosystems and human well-being-Synthesis Report: Washington D.C., Island Press.

NASA, 2006, MODIS Land Cover Type, compiled using Headwaters Economics Economic profile system-human dimensions toolkit

Netusil, N.R., Boyd, E., Griffen, Z.V., LaMerrill, M., and Rainsberger, E., 2000, Can open space be selffinancing?: Choices, v. 15, no. 2, p. 21-23.

Phillips, S., 2000, Windfalls for wilderness - Land protection and land value in the Green Mountains, in McCool, S.F., Cole, D.N., Borrie, W.T., and O'Loughlin, J., Wilderness science in a time of change conference-Volume 2-Wilderness in the contect of larger systems, Missoula, Mont., May 23-27, 1999: Proceedings RMRS-P-15-VOL-2:258-267: Ogden, Utah, U.S. Department of Agriculture, Forest Service, Rocky Mountain Research Station.

Reynolds, R., Shaffer, T., Renner, R., Newton, W., and Batt, B., 2001, Impact of the Conservation Reserve Program on duck recruitment in the U.S. Prairie Pothole region: Journal of Wildlife Management, v. 65, no. 4, p. 765-780. 
Rich, T.D., Wisdom, M.J., and Saab, V.A., 2005, Conservation of sagebrush steppe birds in the interior Columbia Basin, General Techinical Report PSW-GTR-191, in Ralph, C.J., Rich, T., and Long, L., International Partners in Flight Conference, $3^{\text {rd }}$, Albany, Calif., September 05, 2011, Proceedings: Washington D.C., U.S. Departments of Agriculture, Forest Service, Pacific Southwest Research Station, p. 589-606.

Rissman, A., Lozier, L., Comendant, T., Kareiva, P., Kiesecker, J., Shaw, M., and others, 2007, Conservation easements-Biodiversity protection and private use: Conservation Biology, v. 21, no. 3, p. 709-718.

Rowland, M.M., Wisdom, M.J., Meinke, C.W., and Suring, L.H., 2005, Utility of greater sage-grouse as an umberlla species, in Wisdom, M.J., Rowland, M.M., and Suring, L.H., Habitat threats in the sagebrush ecosystem-Methods of regional assessment and applications in the Great Basin: Lawrence, Kans., Allen Press, p. 232-249.

Royster, W., and Gearino, J., 2006, Squeezed in Star Valley: Casper, Wyo., Casper Star Tribune. [October 15]

State of Idaho Department of Labor, 2011, Migration to urban Idaho persisted in 2000's: Boise, Idaho, State of Idaho Department of Labor, accessed online September 05, 2011, at http://labor.Idaho.gov/NEWS/Default.aspx?Tabid=1953andctl=PressReleaseandmid=2527anditemid= 2302andAspxAutoDetectCookieSupport=1. [Press release on March 10, 2011]

Taylor, D.T., and Coupal, R.H., 2000, The cost of rural community services in Laramie, Wyoming: Laramie, Wyo., University of Wyoming, Department of Agricultural and Applied Economics.

The Nature Conservancy, 2010, Tri-State Bear River CAP: Arlington, Va., The Nature Conservancy, accessed online September 05, 2011, at http://conpro.tnc.org/1561/.

Thorsnes, P., 2002, The value of a suburban forest preserve-Estimates from sales of vacant residential building lots: Land Economics, v. 78, no. 3, p. 426-441.

Toth, R.E., Edwards, T.C., Perschon, A.L., and White, D.C., 2010, Bear River Watershed-Its role in maintaining the Bear River Migratory Bird Refuge_Final Project Report no. 2010-1, U.S. Geological Survey: Logan, Utah, Utah Cooperative Fish and Wildlife Research Unit, Utah State Universiy.

U.S. Department of Agriculture, 2009, Census of Agriculture, (Table 8): Washington, D.C. National Agricultural Statistics Service, compiled using Headwaters Economics Economic profile system-human dimensions toolkit

U.S. Census Bureau, 2009, Small area income and povery estimates: Washington D.C., U.S. Census Bureau, accessed online November 14, 2011, at http://www.census.govl/did/www/saipe/

U.S. Census Bureau, 2010, State and county quickfacts: Washington D.C., U.S. Census Bureau, accessed online November 14, 2011, at http://quickfacts.census.gov/qfd/index.html

U.S. Census Bureau, 2011, American factfinder: Washington D.C., U.S. Census Bureau, accessed online November 14, 2011, at http://factfinder2.census.gov/main.html

U.S. Department of Commerce, 2010a, Regional Economic Information System, (Table CA25N \& CA25N): Washington, D.C., Bureau of Economic Analysis, compiled using Headwaters Economics Economic profile system-human dimensions toolkit

U.S. Department of Commerce, 2010b, County business patterns: Washington, D.C., Census Bureau, compiled using Headwaters Economics Economic profile system-human dimensions toolkit

U.S. Fish and Wildlife Service, 2008, 2006 National survey of fishing, hunting, and wildlife-Associated recreation: Washington D.C., U.S. Fish and Wildlife Service and U.S. Census Bureau, 164 p.

U.S. Fish and Wildlife Service, 2010, Preliminary project proposal-Bear River Watershed Conservation Area: Washington D.C., U.S. Fish and Wildlife Service.

Urban Institute and Brookings Institution, 2008, State and local tax policy-What are the sources of revenue for local governments?: Washington D.C., Tax Policy Center, accessed online July 18, 2011, available at http://www.taxpolicycenter.org/briefing-book/state-local/revenues/local_revenue.cfm 
Utah Division of Water Resources, 2004, Bear River Basin_Planning for the future: Salt Lake City, Utah, Utah Division of Water Resources, $105 \mathrm{p}$.

Utah Governors Office of Planning and Budget, 2008, 2008 Utah baseline-Current conditions, trends, and projections: Salt Lake City, Utah, Governors Office of Planning and Budget, Envision Utah, and the Utah Quality Growth Commission.

Utah State University Extension, 2006, Journey through the Bear River Watershed-Project Wet International Foundation: Logan, Utah, Utah State University Cooperative Extension, accessed online September 05, 2011, at http://extension.usu.edu /waterqualtiy/filesupload.

Utah Water Research Laboratory, 2011, Bear River Watershed Information System: Logan, Utah, Utah Water Research Laboratory, Utah State University, accessed online September 05, 2011, at http://www.bearriverinfo.org/

Utah.gov, 2011, The Utah Farmland Assessment Act: Salt Lake City, Utah, Utah State Tax Commission, accessed online September 05, 2011, at http://propertytax.utah.gov/faa/faa.html

Van Every, L., 2004, Water quality impacts from selenium and other metals in the southeastern Idaho phosphate mining resource area, in The Rocky Mountain (56th Annual) and Cordilleran (100th Annual) Joint Meeting, Boise, Idaho, May 3-5, 2004, Proceedings: Boulder, Colo., Geological Society of America, accessed online September 05, 2011, at http://gsa.confex.com/gsa/2004RM/finalprogram/abstract_71959.htm

Vrooman, D., 1978, An empirical analysis of determinants of land values in the Adriondack Park: American Journal of Economics and Sociology, v. 37, no. 2, p. 165-177.

Wyoming Department of Revenue, 2011, Property tax FAQ: Cheyenne, Wyo., Wyoming Department of Revenue, accessed online September 05, 2011, at http://revenue.state.wy.us/portalvbvs/desktopdefault.aspx? tabindex $=4$ andtabid $=11$

For more information concerning this publication, contact:

Center Director, USGS Fort Collins Science Center

2150 Centre Ave., Bldg. C

Fort Collins, CO 80526-8118

(970) 226-9398

Or visit the Fort Collins Science Center Web site at:

http://www.fort.usgs.gov/ 